\title{
Trophic uptake and transfer of DMSP in simple planktonic food chains
}

\author{
Kam W. Tang ${ }^{1,3, *}$, Rafel Simó ${ }^{2}$ \\ ${ }^{1}$ Danish Institute for Fisheries Research, Kavalergården 6, Charlottenlund 2920, Denmark \\ ${ }^{2}$ Institut de Ciències del Mar, Passeig Marítim de la Barceloneta 37-49, 08003 Barcelona, Catalonia, Spain \\ ${ }^{3}$ Present address: Virginia Institute of Marine Science, PO Box 1346, Gloucester Point, Virginia 23062, USA
}

\begin{abstract}
Recent field studies suggest that a large portion of phytoplankton-DMSP could be lost to grazing by protozoans, but the fate of the grazed DMSP remains uncertain. In the laboratory we studied trophic uptake and transfer of phytoplankton-DMSP through simple planktonic food chains using 2 experimental approaches: (1) A direct approach measured the ingestion and retention of phytoplankton-DMSP by the heterotrophic dinoflagellate Gyrodinium dominans. Overall, DMSP content of $G$. dominans estimated by the direct approach was highly variable, likely because of the low G. dominans biomass relative to phytoplankton in the samples. (2) An indirect approach, in which the omnivorous copepod Acartia tonsa was allowed to prey on a mixture of phytoplankton and G. dominans. Using this indirect approach, A. tonsa retained a high concentration of G. dominans biomass in its guts. Combined with other feeding parameters, the copepod gut contents were used to derive the DMSP content of G. dominans. When fed on Phaeocystis globosa, G. dominans retained $1.64 \times 10^{-4} \mathrm{nmol}$ DMSP cell ${ }^{-1}$, or $44 \%$ of the grazed DMSP. When fed on Isochrysis galbana, the protozoan retained $6.87 \times 10^{-5} \mathrm{nmol}$ DMSP cell ${ }^{-1}$, or $32 \%$ of the grazed DMSP. A. tonsa selectively preyed on G. dominans when offered a mixture of G. dominans and phytoplankton, deriving 63 to $84 \%$ of their dietary DMSP from the protozoan. Our study suggests that protozoans are an important trophic linkage to transfer phytoplankton-DMSP up food chains, and that the effectiveness of this linkage is dependent on the species composition of both the phytoplankton and the higher trophic levels.
\end{abstract}

KEY WORDS: Sulfur cycle $\cdot$ Dimethylsulfide $\cdot$ Dimethylsulfoniopropionate $\cdot$ Microzooplankton · Mesozooplankton

Resale or republication not permitted without written consent of the publisher

\section{INTRODUCTION}

The climatically active gas DMS is a breakdown product of DMSP, one of several osmolytes synthesized by phytoplankton (Keller \& Korjeff-Bellows 1996, Kirst 1996, Welsh 2000). DMS accounts for $>90 \%$ of sea-air exchange of biogenic sulfur (Lovelock et al. 1972, Nguyen et al. 1978, 1983, Andreae \& Raemdonck 1983). Once in the atmosphere, DMS further reacts to form cloud condensation nuclei, thereby affecting the global radiation budget (Charlson et al. 1987, Andreae 1990). While DMSP is synthesized by phytoplankton, the conversion of DMSP to DMS is regulated by complex trophic processes in the water column (Kiene et al. 2000, Tang et al. 2000b, Simó 2001). Global measure- ments show poor correlations between DMS and parameters directly related to primary producers (e.g. seston-DMSP, chlorophyll, dissolved nutrients; Kettle et al. 1999), further confirming that factors other than phytoplankton play important roles in oceanic DMS and DMSP dynamics. Recent field studies show that a significant portion of phytoplankton-DMSP is consumed by grazers. For example, $91 \%$ of the phytoplanktonDMSP loss was mediated by microzooplankton grazing during an Emiliania huxleyi bloom in the northern North Sea (Archer et al. 2002). In the North Atlantic, microzooplankton ingested on average $44 \% \mathrm{~d}^{-1}$ of the particulate DMSP stock, accounting for $63 \%$ of the algal DMSP loss per day (Simó et al. 2002). Quantitative information on mesozooplankton grazing of phyto- 
plankton-DMSP is largely limited to laboratory studies (e.g. Kwint et al. 1996a, Tang et al. 1999). Mesocosm studies, however, suggest that when the phytoplankton community is dominated by small species, mesozooplankton control DMS and DMSP dynamics mainly by preying on microzooplankton (Kwint et al. 1996b, Levasseur et al. 1996). Although zooplankton grazing of phytoplankton-DMSP has been discussed frequently, what is less clear is the fate of the grazed DMSP. Several investigators have shown that grazing sometimes promotes DMS production (Christaki et al. 1996, Daly \& DiTullio 1996, Kwint et al.1996b) due to sloppy feeding (Dacey \& Wakeham 1986, but see Tang et al. 2000a), or enhanced DMSP-lyase activities in damaged phytoplankton cells (Wolfe \& Steinke 1996). Through these mechanisms grazing may accelerate the conversion of DMSP to DMS and possibly the sea-air exchange of sulfur. On the other hand, if grazers accumulated ingested DMSP, they would retain DMSP within the food web (Belviso et al. 1990), transfer it up food chains (e.g. Levasseur et al. 1994) and thereby uncouple DMSP and DMS productions.

Among the planktonic grazers, copepods have been shown to accumulate DMSP in their guts or body tissues after feeding on phytoplankton (Tang et al. 1999, 2000a, Tang 2000). Whether protozoans retain ingested DMSP is less certain, and so far only indirect evidence is available: (1) Imbalances in budgeting the phytoplankton stock and production of DMSP and all measured DMSP losses in grazing studies are attributed to uptake by protozoans (Wolfe et al. 1994, Archer et al. 2001, Simó et al. 2002). (2) Field-collected omnivorous and carnivorous copepods contain DMSP in their bodies, which is likely derived from ingested protozoans (Tang et al. 1999, 2000b). Measuring protozoan-bound DMSP is difficult because most protozoans are fragile and similar in size to phytoplankton and therefore cannot be isolated easily. This is particularly problematic with field samples where protozoan biomass is generally similar to, or lower than, phytoplankton biomass. An alternative approach would be to measure DMSP in concentrated protozoan biomass in the laboratory, provided that the amount of DMSP from coexisting phytoplankton cells is known.

Our goal was to study the trophic uptake and transfer of DMSP through simple planktonic food chains. Specific objectives were to: (1) measure DMSP retention (assimilated or temporarily stored in food vacuoles) by protozoans, (2) study DMSP dynamics within simple food chains of copepod, protozoan and phytoplankton, and (3) study speciesspecific differences by using 2 phytoplankton species for all experiments. Our results show that the pelagic food web structure plays important roles in DMSP dynamics because of retention of ingested DMSP in protozoan biomass and selective feeding by copepods on protozoans.

\section{MATERIALS AND METHODS}

Phytoplankton and grazers. The phytoplankton and grazer species used in the present study are listed in Table 1. Non-axenic inocula of Phaeocystis globosa CCMP 1528 and Isochrysis galbana (Prymnesiophyceae) were respectively obtained from Bigelow Laboratory (Maine, USA) and University of Copenhagen (Denmark). P. globosa is a major DMSP producer (e.g. van Duyl et al. 1998) that frequently forms massive blooms in coastal waters (Lancelot et al. 1998). I. galbana is another common coastal prymnesiophyte that produces DMSP (Christaki et al. 1996, Niki et al. 2000). Phytoplankton cultures were grown in aerated L-medium at $19 \pm 1^{\circ} \mathrm{C}, 60$ to $100 \mu \mathrm{E} \mathrm{m} \mathrm{m}^{-2} \mathrm{~s}^{-1}$ with a 12:12 h dark:light cycle. The cultures were maintained in active growth by regular dilution with fresh medium. Because P. globosa is able to form large spherical colonies, single $P$. globosa cells were obtained by filtering the culture through an $11 \mu \mathrm{m}$ sieve under gravity prior to experiments (Jakobsen \& Tang 2002). The cosmopolitan heterotrophic dinoflagellate Gyrodinium dominans was originally isolated from Øresund, Denmark, and maintained in L-medium with the experimental diets for $>5$ generations before

Table 1. Phytoplankton and grazer species studied. Size of live phytoplankton cells was measured by Elzone particle sizer. Phytoplankton carbon content is estimated according to Strathmann (1967). Carbon content of Gyrodinium dominans is estimated according to Menden-Deuer \& Lessard (2000)

\begin{tabular}{|c|c|c|c|}
\hline Species & $\begin{array}{l}\text { Taxonomic } \\
\text { group }\end{array}$ & $\begin{array}{l}\text { Cell size } \\
\quad(\mu \mathrm{m})\end{array}$ & $\begin{array}{l}\text { Carbon content } \\
\left(\mathrm{pg} \mathrm{C} \mathrm{cell}{ }^{-1}\right)\end{array}$ \\
\hline $\begin{array}{l}\text { Phaeocystis } \\
\text { globosa }\end{array}$ & Prymnesiophyte & 4.4 & 9.3 \\
\hline $\begin{array}{l}\text { Isochrysis } \\
\text { galbana }\end{array}$ & Prymnesiophyte & 4.2 & 8.2 \\
\hline $\begin{array}{l}\text { Gyrodinium } \\
\text { dominans }\end{array}$ & $\begin{array}{l}\text { Heterotrophic } \\
\text { dinoflagellate }\end{array}$ & $16.6 \pm 2.7^{\mathrm{a}}$ & 314 \\
\hline Acartia tonsa & Calanoid copepod & $500^{\mathrm{b}}$ & \\
\hline \multicolumn{4}{|c|}{$\begin{array}{l}{ }^{\mathrm{a}} \text { G. dominans was fed } I \text {. galbana ad libitum for }>5 \mathrm{~d} \text { and observed under an } \\
\text { inverted microscope with a B/W camera. Video images of live G. dominans } \\
\text { cells were digitized by Videum } 1000^{\mathrm{TM}} \text { video system and analysed by } \\
\text { SigmaScan Pro }{ }^{\mathrm{TM}} \text { software for cell size (mean } \pm \mathrm{SD} \text { ) } \\
{ }^{\mathrm{b}} \text { Value for } A \text {. tonsa is approximate body length }\end{array}$} \\
\hline
\end{tabular}


Table 2. Experimental setup for the incubation experiments. Each type of incubation was run in triplicate. Approximate initial carbon concentrations are given in 2nd and 3rd columns. $\mu_{\mathrm{p}}=$ phytoplankton specific growth rate, $\mu_{\mathrm{G}}=$ Gyrodinium dominans specific growth rate, $I_{\mathrm{G}}=G$. dominans ingestion rate, $I_{\mathrm{A}}=$ Acartia tonsa ingestion rate, $D_{\mathrm{p}=}$ DMSP content of phytoplankton cell, $D_{\mathrm{G}}=\mathrm{DMSP}$ content of $G$. dominans, $D_{\mathrm{A}}=\mathrm{DMSP}$ content of $A$. tonsa

\begin{tabular}{|c|c|c|c|c|c|}
\hline Incubation type & $\begin{array}{l}\text { Phytoplankton } \\
\left(\mathrm{ng} \mathrm{C} \mathrm{ml}^{-1} \text { ) }\right.\end{array}$ & $\begin{array}{l}\text { Gyrodinium dominans } \\
\quad\left(\mathrm{ng} \mathrm{C} \mathrm{ml}^{-1}\right)\end{array}$ & $\begin{array}{l}\text { Acartia tonsa } \\
\text { (total no.) }\end{array}$ & $\begin{array}{l}\text { Sampling } \\
\text { frequency }\end{array}$ & $\begin{array}{l}\text { Parameter } \\
\text { derived }\end{array}$ \\
\hline \multicolumn{6}{|c|}{ Phaeocystis globosa } \\
\hline 1 & 230 & 0 & 0 & Day $0,1,2,4,6,8$ & $\mu_{\mathrm{P}}, D_{\mathrm{P}}$ \\
\hline 2 & 204 & 30 & 0 & Day $0,2,4,6,8$ & $\mu_{\mathrm{G}}, I_{\mathrm{G}}, D_{\mathrm{G}}$ \\
\hline 3 & 235 & 0 & 10 & Day 0,1 & $I_{\mathrm{A}}, D_{\mathrm{A}}$ \\
\hline 4 & 172 & 38 & 10 & Day 0,1 & $I_{\mathrm{A}}, D_{\mathrm{A}}$ \\
\hline \multicolumn{6}{|c|}{ Isochrysis galbana } \\
\hline 1 & 66 & 0 & 0 & Day $0,1,2,4,6,8$ & $\mu_{\mathrm{P}}, D_{\mathrm{P}}$ \\
\hline 2 & 66 & 21 & 0 & Day $0,2,4,6,8$ & $\mu_{\mathrm{G}}, I_{\mathrm{G}}, D_{\mathrm{G}}$ \\
\hline 3 & 147 & 0 & 10 & Day 0,1 & $I_{\mathrm{A}}, D_{\mathrm{A}}$ \\
\hline 4 & 79 & 29 & 10 & Day 0,1 & $I_{\mathrm{A}}, D_{\mathrm{A}}$ \\
\hline
\end{tabular}

experiments. The size of live phytoplankton cells was measured using an Elzone particle sizer, whereas the size of live $G$. dominans was estimated from digitized video images. The cellular carbon contents of the phytoplankton and G. dominans were calculated from cell size according to Strathmann (1967) and MendenDeuer \& Lessard (2000). The common omnivorous calanoid copepod Acartia tonsa was used for the present study. Nauplii of $A$. tonsa were hatched from eggs and cohorts were raised on a food mixture of Rhodomonas salina (Chrysophyceae) and Thalassiosira weissflogii (Bacillariophyceae). Adult A. tonsa (within 4 wk from hatching) were collected for subsequent experiments.

For each phytoplankton species, 4 types of bottle incubation experiments were conducted simultaneously. Adult Acartia tonsa females were starved in filtered seawater (FSW) for $2 \mathrm{~d}$ to empty their gut contents prior to experiments. Phytoplankton and Gyrodinium dominans cultures were diluted with L-medium to the desired concentrations for the experiments. Preliminary experiments showed that Isochrysis galbana grew at a high rate; therefore, to avoid fouling by excessive phytoplankton concentration, the initial concentration of $I$. galbana was adjusted to lower than that of Phaeocystis globosa in all experiments. All incubations were done in $315 \mathrm{ml}$ glass bottles (triplicate) at $19 \pm 1^{\circ} \mathrm{C}, 60$ to $100 \mu \mathrm{E}$ $\mathrm{m}^{-2} \mathrm{~s}^{-1}$ with a $12: 12 \mathrm{~h}$ dark:light cycle. The bottles were fastened to a rotating plankton wheel $(0.4 \mathrm{rpm})$ to maintain particles in suspension. Bottle content, incubation duration, and parameters derived from each experiment are summarized in Table 2. Additional explanations for the experiments are given below.

Phytoplankton measurements (Incubation Type 1). Phytoplankton were incubated for $8 \mathrm{~d}$. Aliquots were drawn with pipettes and preserved in $4 \%$ acid Lugol's solution for cell counts (in Sedgewick-Rafter counting chambers). To measure cellular DMSP content, $10 \mathrm{ml}$ aliquots were sampled with a glass syringe and slowly filtered onto GF/F filter papers. The filter papers were transferred to cryogenic vials and preserved immediately in liquid nitrogen until DMSP measurements were taken (Simó et al. 1998).

Protozoan measurements (Incubation Type 2). Gyrodinium dominans was incubated with phytoplankton and the change in cell concentrations was followed for $8 \mathrm{~d}$. Aliquots were drawn every second day for cell counts (settling chambers for $G$. dominans and Sedgewick-Rafter counting chambers for phytoplankton cells). Additional $10 \mathrm{ml}$ aliquots were drawn from each incubation bottle with a glass syringe and slowly filtered onto GF/F filter papers; the filter papers were transferred to cryogenic vials and preserved immediately in liquid nitrogen until DMSP measurements were taken. DMSP content of G. dominans was calculated after correcting for DMSP from phytoplankton based on cell counts and DMSP content of the phytoplankton cells.

Direct grazing experiments with copepods (Incubation Type 3). Starved Acartia tonsa (10 in triplicate) were removed, briefly rinsed in FSW and preserved in liquid nitrogen for background DMSP; groups of $10 \mathrm{~A}$. tonsa were incubated with phytoplankton for $1 \mathrm{~d}$. At the end of the incubation, aliquots of the bottle content were preserved for phytoplankton cell counts. The copepods were removed, rinsed and preserved for DMSP measurements.

Tri-trophic feeding experiments with protozoans and copepods (Incubation Type 4). Starved Acartia tonsa (10 in triplicate) were incubated with a mixture of Gyrodinium dominans and phytoplankton. After $1 \mathrm{~d}$ of incubation, aliquots were preserved for $G$. dominans and phytoplankton cell counts and the copepods were collected for DMSP measurements. 
DMSP measurements. Samples were transported to Barcelona, frozen in dry ice. DMSP was quantitatively converted to DMS by alkaline hydrolysis $(\mathrm{NaOH})$ of the filters and copepod individuals in air-tight vials filled with Milli-Q water, in the dark, at room temperature, for 18 to $24 \mathrm{~h}$. The evolved DMS was determined following purge, cryotrapping and sulfur-specific gas chromatography procedures described elsewhere (Simó et al. 1996). The detection limit was 30 pmol.

Calculation of growth rates and ingestion rates. Growth rates of phytoplankton were derived from Days 0 to 2 of Incubation Type 1 assuming exponential growth. Growth and feeding rates of Gyrodinium dominans in Incubation Type 2 were derived from cell counts between Days 0 and 2 when food was not limiting: Growth rate was calculated assuming exponential growth, and ingestion rate was calculated using the iterative approach as described in Jakobsen \& Hansen (1997) and Tang et al. (2001a), assuming that the phytoplankton growth rates did not differ between the grazing treatments and the controls. Ingestion rates of Acartia tonsa on phytoplankton in the direct grazing experiments (Incubation Type 3) were calculated
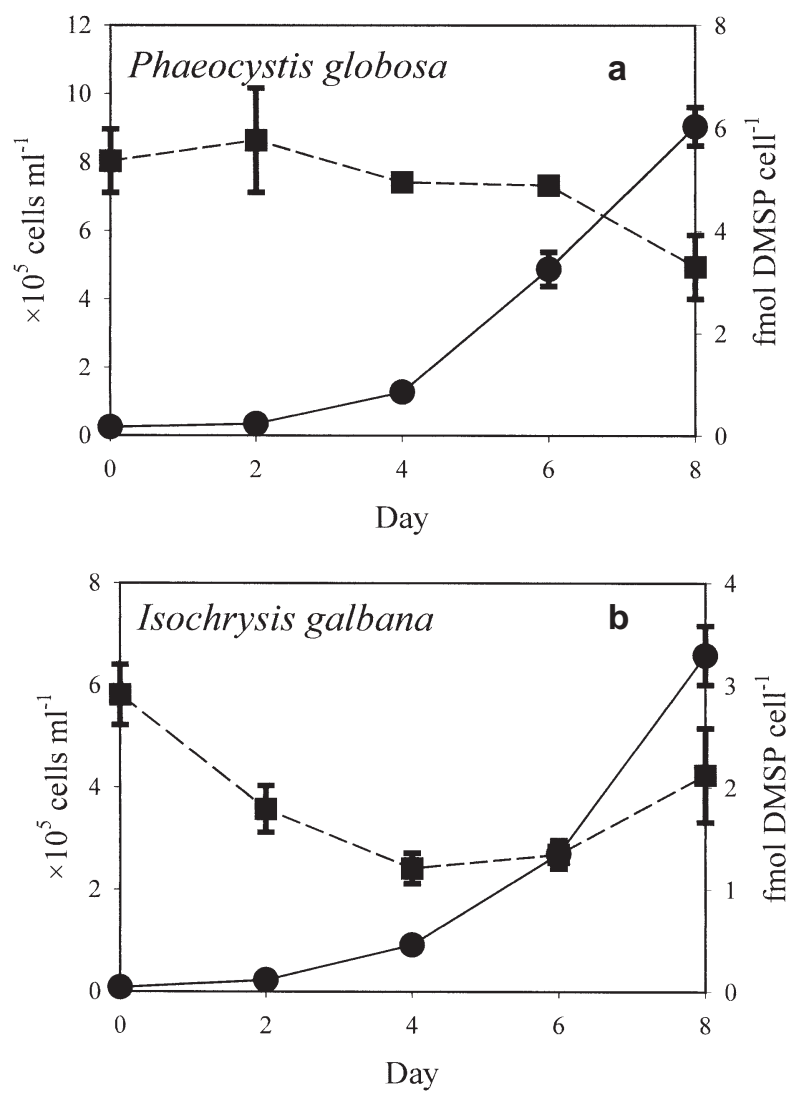

Fig. 1. Cell concentrations ( $\bullet$ mean $\pm \mathrm{SD}$ of triplicates) and DMSP contents ( $\boldsymbol{\square}_{\text {; }}$ mean \pm SD of 2 to 3 replicates $)$ of (a) Phaeocystis globosa and (b) Isochrysis galbana according to Frost (1972). In the tri-trophic experiments (Incubation Type 4), the ingestion rate of $A$. tonsa on $G$. dominans was calculated according to Frost (1972). The phytoplankton cells were eaten by both $G$. dominans and A. tonsa, while G. dominans were eaten by $A$. tonsa at the same time; thus, the rate of ingestion of phytoplankton cells by $A$. tonsa had to be calculated by solving coupled non-linear equations as explained in Tang et al. (2001a).

Experiment with Dunaliella tertiolecta. To further test the hypothesis that Gyrodinium dominans obtain DMSP from food, we conducted an additional experiment in which $G$. dominans were incubated with the chlorophyte $D$. tertiolecta. D. tertiolecta produces no or little DMSP (Tang et al. 1999); therefore, G. dominans is expected to contain no or little DMSP when fed $D$. tertiolecta. G. dominans that had been growing for $>5$ generations on a diet of $D$. tertiolecta were incubated with D. tertiolecta for 1 d (970 G. dominans + 35000 D. tertiolecta $\mathrm{ml}^{-1}$, quadruplicate), and aliquots were collected for DMSP measurements. Ten ml aliquots of dense $D$. tertiolecta culture $\left(1.45 \times 10^{5} \mathrm{ml}^{-1}\right.$; quadruplicate) were also collected for DMSP measurements.

\section{RESULTS}

\section{Experiments with Phaeocystis globosa}

Phaeocystis globosa grew exponentially from Days 2 to 8 during the experimental period, during which time the cellular DMSP averaged $4.86 \mathrm{fmol} \mathrm{cell}^{-1}(\mathrm{SD}=$ $0.96 \mathrm{fmol} \mathrm{cell}^{-1}$ ) (Fig. 1). This average value was used for subsequent calculations. After 2 d starvation, Acartia tonsa contained a negligible amount of DMSP (below detection limit), confirming that this species accumulates no or little DMSP in the absence of DMSP-containing food (Tang 2000). When fed on $P$. globosa alone (Incubation Type 3), A. tonsa ingested $3.07 \mu \mathrm{g} \mathrm{C}$ ind..$^{-1} \mathrm{~d}^{-1}$ (mean filtration rate $15.2 \mathrm{ml}$ ind. ${ }^{-1}$ $\mathrm{d}^{-1}$ ) or $1.60 \mathrm{nmol}$ DMSP ind. ${ }^{-1} \mathrm{~d}^{-1}$ (Fig. 2). This ingestion rate was higher than that reported in Tang et al. (2001a), likely a result of an elevated ingestion rate after starvation (Tiselius 1998). At the end of the incubation, A. tonsa bodies contained only $0.068 \mathrm{nmol}$ DMSP ind. $^{-1}$, or $4.3 \%$ of the total ingested DMSP (Fig. 2). If the copepods contained DMSP as gut content, and assuming the gut content was at steady state, the gut passage time $(T)$ can be expressed as a function of DMSP gut content $(G)$ and ingestion rate $(I)$ :

$$
T=\frac{G}{I}
$$

In this experiment, the estimated gut passage time was $61 \mathrm{~min}$, consistent with the general gut passage 
a

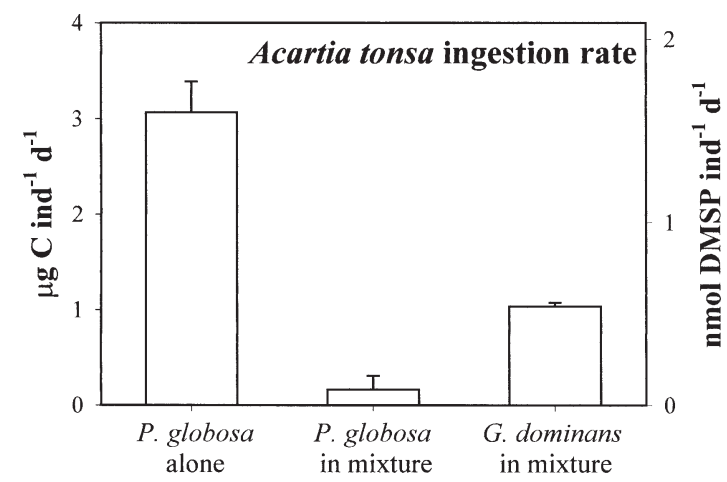

b

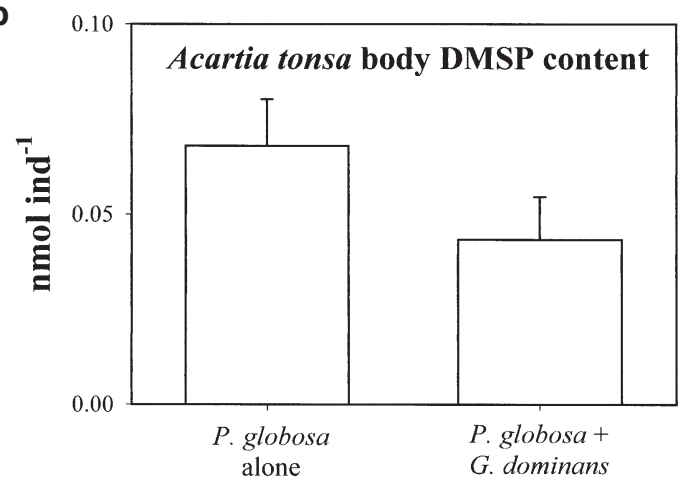

Fig. 2. Phaeocystis globosa experiments. (a) Carbon (left axis) and DMSP (right axis) ingestion rates of Acartia tonsa in single food treatment $(P$. globosa) and mixed food treatment $(P$. globosa + Gyrodinium dominans). See text for derivation of DMSP content of $G$. dominans. (b) DMSP content of $A$. tonsa in single food treatment and mixed food treatment. Error bars are $+\mathrm{SD}$ of triplicates

times for calanoid copepods (to the order of $1 \mathrm{~h}$ at 17 to $19^{\circ} \mathrm{C}$; Mauchline 1998), further supporting the notion that $A$. tonsa contained DMSP as gut content.

When fed on a mixture of Phaeocystis globosa and Gyrodinium dominans (Incubation Type 4), Acartia tonsa ingested a lower amount of total carbon $\left(1.20 \mu \mathrm{g}\right.$ ind $\left.^{-1} \mathrm{~d}^{-1}\right)$, similar to earlier observations (Tang et al. 2001a). Although G. dominans and $P$. globosa were mixed at a ratio of 1:4.5 in terms of carbon concentrations, A. tonsa selectively fed on $G$. dominans, deriving $86 \%$ of the total carbon intake from G. dominans (Fig. 2), also consistent with previous observations (Tang et al. 2001a). Mean filtration rates of $A$. tonsa in the mixed food treatment were 1.5 and $32.5 \mathrm{ml}$ ind..$^{-1} \mathrm{~d}^{-1}$ on P. globosa and G. dominans, respectively. Since $A$. tonsa accumulated ingested DMSP in the gut, the observed DMSP content of $A$. tonsa could be combined with ingestion rate to deduce the cellular DMSP content of $G$. dominans. Based on Eq. (1):

$$
\frac{T_{\mathrm{M}}}{T_{\mathrm{P}}}=\frac{G_{\mathrm{M}} / I_{\mathrm{M}}}{G_{\mathrm{P}} / I_{\mathrm{P}}}
$$

where the subscript $M$ denotes parameters for the mixed food treatment and $\mathrm{P}$ for the phytoplankton treatment. Rearranging this equation gives us:

$$
T_{\mathrm{M}}=\frac{G_{\mathrm{M}}}{G_{\mathrm{P}}} \times \frac{I_{\mathrm{P}}}{I_{\mathrm{M}}} \times T_{\mathrm{P}}
$$

Substituting body DMSP contents for parameter $G$ and carbon ingestion rates for parameter $I, T_{\mathrm{M}}$ is estimated to be $98.7 \mathrm{~min}$. Since Acartia tonsa accumulated $0.043 \mathrm{nmol}$ DMSP ind..$^{-1}$ when fed on the food mixture (Fig. 2), this amount of DMSP would be derived from food ingested within one gut passage time, which equalled 1214 Phaeocystis globosa cells and 226 Gyrodinium dominans cells. Based on the average DMSP content of $P$. globosa from Incubation Type 1, ingested DMSP due to $P$. globosa cells equalled $5.90 \times 10^{-3}$ nmol. The remaining $0.037 \mathrm{nmol}$ DMSP must have come from ingested G. dominans, and the cellular DMSP content of $G$. dominans would therefore be $1.64 \times 10^{-4} \mathrm{nmol} \mathrm{cell}^{-1}$. Knowing the carbon content of G. dominans was $0.31 \mathrm{ng}$ cell $^{-1}$, the carbon-specific DMSP content of G. dominans feeding on P. globosa would be 0.52 pmol DMSP $\mathrm{ng}^{-1} \mathrm{C}$. We define a trophic dilution factor (TDF) as:

$$
\mathrm{TDF}=\frac{\mathrm{C}-\text { specific DMSP content of predator }}{\mathrm{C}-\text { specific DMSP content of food }}
$$

Given that the carbon-specific DMSP content of Phaeocystis globosa was $0.52 \mathrm{pmol}$ DMSP $\mathrm{ng}^{-1} \mathrm{C}$, the TDF between Gyrodinium dominans and P. globosa was $0.52 / 0.52=1.00$. From Incubation Type 2, G. dominans had an ingestion rate of $36.2 P$. globosa cells ind. ${ }^{-1} \mathrm{~d}^{-1}$ and a specific growth rate $(\mu)$ of $0.66 \mathrm{~d}^{-1}$. Since $G$. dominans grew by binary fission, the generation time of $1 \mathrm{G}$. dominans cell can be calculated as $\ln 2 / \mu=1.05 \mathrm{~d}$. Thus, before dividing, G. dominans ingested 38 P. globosa cell ind. ${ }^{-1}$, or $1.85 \times 10^{-4} \mathrm{nmol}$ DMSP ind. ${ }^{-1}$, of which $0.5 \times 1.64 \times 10^{-4} \mathrm{nmol}$ was retained by the cell (the factor 0.5 is to correct for DMSP inherited from parent cell under steady-state condition). Therefore, the trophic uptake efficiency of DMSP by G. dominans feeding on P. globosa was $44 \%$, and the DMSP removal efficiency was $(100-44) \%=$ $56 \%$. The removal efficiency indicates the missing portion of the ingested DMSP, which could be degraded or excreted by the protozoan or released during digestion of the alga by the protozoan.

The DMSP content of Gyrodinium dominans can be independently calculated using data from Incubation Types 1 and 2, in which cell concentrations and particulate DMSP concentrations were measured every $2 \mathrm{~d}$, for a total of $8 \mathrm{~d}$. The average DMSP content of Phaeocystis globosa cells determined from Incubation Type 1 was $4.86 \mathrm{fmol} \mathrm{cell}^{-1}$. Applying this value to Incubation Type 2, we calculated the particulate DMSP concentra- 
Table 3. Cellular DMSP content of Gyrodinium dominans feeding on Phaeocystis globosa as derived from Incubation Type 2. Average DMSP content of $P$. globosa was obtained from Incubation Type 1 (see Fig. 1)

\begin{tabular}{|c|c|c|c|c|c|c|}
\hline Day & $\begin{array}{l}\text { G. dominans } \\
\left(\text { cells } \mathrm{ml}^{-1}\right)\end{array}$ & 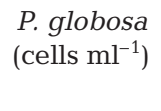 & $\begin{array}{c}\text { Total particulate } \\
\text { DMSP } \\
\left(\mathrm{nmol} \mathrm{ml}^{-1}\right)\end{array}$ & $\begin{array}{l}\text { DMSP from } \\
P . \text { globosa } \\
\left(\mathrm{nmol} \mathrm{ml}^{-1}\right)\end{array}$ & $\begin{array}{l}\text { DMSP from } \\
\text { G. dominans } \\
\left(\mathrm{nmol} \mathrm{ml}^{-1}\right)\end{array}$ & $\begin{array}{l}\text { DMSP content } \\
\text { of } G \text {. dominans } \\
\left(\mathrm{nmol} \text { cell }^{-1}\right)\end{array}$ \\
\hline 0 & 93.7 & 21967 & 0.11 & $1.07 \times 10^{-1}$ & $1.05 \times 10^{-3}$ & $1.12 \times 10^{-5}$ \\
\hline 2 & 349.4 & 14383 & 0.06 & $6.99 \times 10^{-2}$ & $-5.96 \times 10^{-3}$ & $-1.71 \times 10^{-5}$ \\
\hline 4 & 582.5 & 9361 & 0.05 & $4.55 \times 10^{-2}$ & $5.62 \times 10^{-3}$ & $9.65 \times 10^{-6}$ \\
\hline 6 & 450.3 & 8511 & 0.12 & $4.14 \times 10^{-2}$ & $7.46 \times 10^{-2}$ & $1.66 \times 10^{-4}$ \\
\hline 8 & 170.6 & 46011 & 0.23 & $2.24 \times 10^{-1}$ & $1.06 \times 10^{-2}$ & $6.19 \times 10^{-5}$ \\
\hline & & & & & \multicolumn{2}{|c|}{ Average $6.22 \times 10^{-5}\left(4.63 \times 10^{-5}\right)^{\mathrm{a}}$} \\
\hline
\end{tabular}

tion derived from P. globosa cells, and the difference of that from the observed particulate DMSP concentration would be DMSP derived from G. dominans cells. The calculated values show considerable scatter (Table 3). The value that agrees best with the previous estimate was from Day $6\left(1.66 \times 10^{-4} \mathrm{nmol}\right.$ cell $\left.^{-1}\right)$ when the DMSP signal from $P$. globosa was relatively small. The cellular DMSP content of $G$. dominans averaged $4.63 \sim 6.22 \times 10^{-5} \mathrm{nmol} \mathrm{cell}^{-1}$ over $8 \mathrm{~d}$.

a

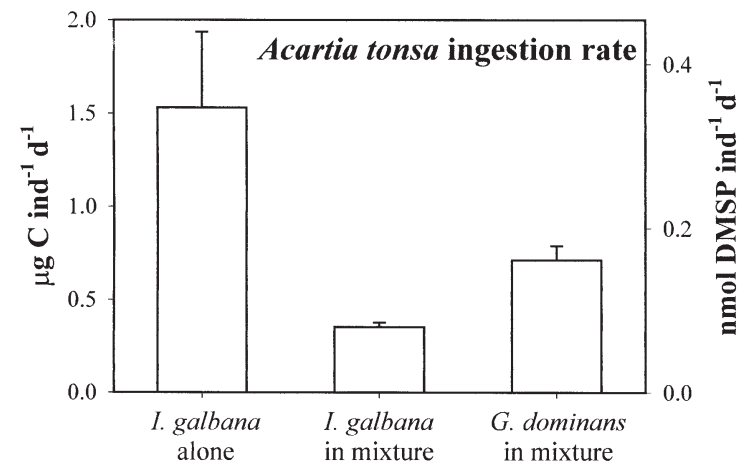

b

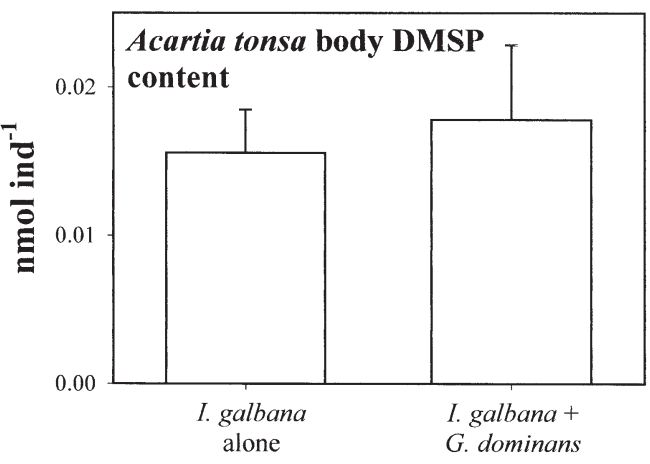

Fig. 3. Isochrysis galbana experiments. (a) Carbon (left axis) and DMSP (right axis) ingestion rates of Acartia tonsa in single food treatment (I. galbana) and mixed food treatment (I. galbana + Gyrodinium dominans). See text for derivation of DMSP content of G. dominans. (b) DMSP content of A. tonsa in single food treatment and mixed food treatment. Error bars are + SD of triplicates

\section{Experiments with Isochrysis galbana}

The cellular DMSP content of Isochrysis galbana varied during exponential growth and averaged $1.86 \mathrm{fmol} \mathrm{cell}^{-1}$ (SD = $0.66 \mathrm{fmol} \mathrm{cell}^{-1}$ ) over $8 \mathrm{~d}$ (Fig. 1). When fed only on $I$. galbana, Acartia tonsa ingested $1.57 \mu \mathrm{g} \mathrm{C}$ ind..$^{-1} \mathrm{~d}^{-1}$ (mean filtration rate $9.4 \mathrm{ml}$ ind. ${ }^{-1}$ $\mathrm{d}^{-1}$ ) (Fig. 3) or $0.35 \mathrm{nmol}$ DMSP ind.$^{-1} \mathrm{~d}^{-1}$, and retained 0.016 nmol DMSP ind ${ }^{-1}$ (Fig. 3). Thus, the estimated gut passage time was $65.8 \mathrm{~min}$. When fed a mixture of $I$. galbana and Gyrodinium dominans, A. tonsa ingested $1.06 \mu \mathrm{g} \mathrm{C}$ ind. ${ }^{-1} \mathrm{~d}^{-1}$ (Fig. 3) and retained $0.018 \mathrm{nmol}$ DMSP ind.$^{-1}$ (Fig. 3). Although G. dominans made up only $27 \%$ of the carbon concentration in the mixture, $A$. tonsa derived $67 \%$ of their carbon intake by ingesting G. dominans (Fig. 3). Mean filtrate rates of A. tonsa in the mixed food treatment were $5.5 \mathrm{ml}$ ind. ${ }^{-1} \mathrm{~d}^{-1}$ on $I$. galbana and $28.7 \mathrm{ml}$ ind..$^{-1} \mathrm{~d}^{-1}$ on G. dominans. The lower ingestion rate in the mixed food treatment corresponds to a longer gut passage time (Mauchline 1998). From Eq. (2), the estimated gut passage time was $110 \mathrm{~min}$ in the mixed food treatment, during which time A. tonsa would have ingested 3280 I. galbana cells, or $6.10 \times 10^{-3} \mathrm{nmol}$ DMSP from $I$. galbana. In the same duration $A$. tonsa would have ingested $173 \mathrm{G}$. dominans cells, which would account for the remaining $1.19 \times 10^{-2} \mathrm{nmol}$ DMSP in the gut. This gives a cellular DMSP content of $G$. dominans of $6.87 \times 10^{-5} \mathrm{nmol} \mathrm{cell}^{-1}$. Carbon-specific DMSP content of $G$. dominans feeding on I. galbana was $0.22 \mathrm{pmol}$ DMSP ng $\mathrm{C}^{-1}$, lower than that for the Phaeocystis globosa experiments. This indicates that retention of DMSP in G. dominans biomass is dependent on food type. The carbon-specific DMSP content of I. galbana was 0.35 pmol DMSP ng $\mathrm{C}^{-1}$, yielding a TDF of 0.63 between $G$. dominans and $I$. galbana. The generation time of a $G$. dominans cell feeding on $I$. galbana was $1.17 \mathrm{~d}$, during which the cell would have ingested 58.9 I. galbana cells, or $1.09 \times 10^{-4}$ nmol DMSP. Accordingly, the uptake efficiency of DMSP was $32 \%$, and the removal efficiency $68 \%$. 
Table 4. Cellular DMSP content of Gyrodinium dominans feeding on Isochrysis galbana as derived from Incubation Type 2. Average DMSP content of I. galbana was obtained from Incubation Type 1 (see Fig. 1)

\begin{tabular}{|lcccccc|}
\hline Day & $\begin{array}{c}\text { Gyrodinium } \\
\text { dominans } \\
\left(\text { cells ml }^{-1}\right)\end{array}$ & $\begin{array}{c}\text { Isochrysis } \\
\text { galbana } \\
\left(\mathrm{cells} \mathrm{ml}^{-1}\right)\end{array}$ & $\begin{array}{c}\text { Total particulate } \\
\text { DMSP } \\
\left(\mathrm{nmol} \mathrm{ml}^{-1}\right)\end{array}$ & $\begin{array}{c}\text { DMSP from } \\
\text { I. galbana } \\
\left(\mathrm{nmol} \mathrm{ml}^{-1}\right)\end{array}$ & $\begin{array}{c}\text { DMSP from } \\
\text { G. dominans } \\
\left(\mathrm{nmol} \mathrm{ml}^{-1}\right)\end{array}$ & $\begin{array}{c}\text { DMSP content } \\
\text { of G. dominans } \\
\left(\mathrm{nmol} \mathrm{cell}^{-1}\right)\end{array}$ \\
\hline 0 & 64 & 8100 & 0.015 & $1.51 \times 10^{-2}$ & $-9.30 \times 10^{-5}$ & $-1.45 \times 10^{-6}$ \\
2 & 207 & 2467 & 0.007 & $4.60 \times 10^{-3}$ & $2.10 \times 10^{-3}$ & $1.02 \times 10^{-5}$ \\
4 & 289 & 1247 & 0.005 & $2.32 \times 10^{-3}$ & $2.93 \times 10^{-3}$ & $1.02 \times 10^{-5}$ \\
6 & 80 & 817 & 0.004 & $1.52 \times 10^{-3}$ & $2.88 \times 10^{-3}$ & $3.60 \times 10^{-5}$ \\
8 & 9 & 0.005 & $1.82 \times 10^{-3}$ & $2.98 \times 10^{-3}$ & $3.44 \times 10^{-4}$ \\
Average $1.00 \times 10^{-4}$ & & & & \\
\hline
\end{tabular}

Table 5. Estimates of DMSP content of Gyrodinium dominans feeding on Dunaliella tertiolecta. D. tertiolecta contributed negligible DMSP to the samples

\begin{tabular}{|c|c|c|c|c|}
\hline Replicate & $\begin{array}{l}\text { Gyrodinium } \\
\text { dominans } \\
\left(\text { cells ml }{ }^{-1}\right)\end{array}$ & $\begin{array}{r}\text { Dunaliella } \\
\text { tertiolecta } \\
\left(\text { cells } \mathrm{ml}^{-1}\right)\end{array}$ & $\begin{array}{c}\text { Total } \\
\text { particulate } \\
\text { DMSP } \\
\left(\mathrm{nmol} \mathrm{ml}^{-1}\right)\end{array}$ & $\begin{array}{l}\text { DMSP content of } \\
\text { Gyrodinium } \\
\text { dominans } \\
\left(\mathrm{nmol} \mathrm{cell}^{-1}\right)\end{array}$ \\
\hline 1 & 2570 & 3530 & $4.7 \times 10^{-3}$ & $1.83 \times 10^{-6}$ \\
\hline 2 & 2270 & 2800 & $6.4 \times 10^{-3}$ & $2.82 \times 10^{-6}$ \\
\hline 3 & 2450 & 1980 & $6.3 \times 10^{-3}$ & $2.57 \times 10^{-6}$ \\
\hline 4 & 2630 & 2560 & $6.0 \times 10^{-3}$ & $2.28 \times 10^{-6}$ \\
\hline & & & \multicolumn{2}{|c|}{ Average $2.38 \times 10^{-6}$} \\
\hline
\end{tabular}

To measure the DMSP content of Dunaliella tertiolecta, we injected an equivalent of $7 \times 10^{5}$ cells into the reaction-analysis system. The detection limit of the gas chromatograph was 0.03 nmol injection ${ }^{-1}$; thus, the DMSP content of $D$. tertiolecta would be $\leq 4.3 \times 10^{-8} \mathrm{nmol} \mathrm{cell}{ }^{-1}$. The doubling time for Gyrodinium dominans in this experiment was $0.74 \mathrm{~d}$. If we assume that all DMSP came from $D$. tertiolecta, the ingestion rate of $G$. dominans would have been $(2.38 \times$ $\left.10^{-6}\right) \div\left(4.3 \times 10^{-8}\right) \div 0.74=74.8$ cells

The cellular DMSP content of Gyrodinium dominans was independently estimated from Incubation Type 2 (Table 4). Similar to the Phaeocystis globosa experiments, the data show considerable scatter. The closest agreement with the previous estimate was on Day 6 when the Isochrysis galbana concentration was the lowest. The cellular DMSP content of $G$. dominans feeding on $I$. galbana averaged $0.79 \sim 1.00 \times 10^{-4} \mathrm{nmol}$ cell $^{-1}$ over $8 \mathrm{~d}$.

\section{Experiment with Dunaliella tertiolecta}

This additional experiment was designed to further test the hypothesis that Gyrodinium dominans obtains DMSP from its prey. Measurements on a dense Dunaliella tertiolecta culture $\left(\geq 7 \times 10^{5}\right.$ cells sample $\left.{ }^{-1}\right)$ yielded no detectable DMSP. During the experiment, G. dominans grew at an optimal specific growth rate of $0.94 \mathrm{~d}^{-1}$ and had an average DMSP content of $2.38 \times 10^{-6} \mathrm{nmol}$ cell ${ }^{-1}$ (Table 5). Thus, when fed on D. tertiolecta, G. dominans contained 1 to 2 orders of magnitude less DMSP than when fed on Phaeocystis globosa and Isochrysis galbana. These observations support the argument that G. dominans ingestion results in DMSP uptake. Nevertheless, one may ask: Does the small amount of DMSP indicate de novo DMSP synthesis by G. dominans? ind.$^{-1} \mathrm{~d}^{-1}$, or $1.3 \times 10^{4} \mathrm{\mu m}^{3}$ ind..$^{-1} \mathrm{~d}^{-1}$, consistent with the theoretical maximum ingestion rate for heterotrophic dinoflagellates of this size (Hansen et al. 1997). This analysis shows that the small amount of DMSP in $G$. dominans feeding on $D$. tertiolecta does not necessarily indicate de novo DMSP synthesis by G. dominans. Instead, undetectable amounts of DMSP in D. tertiolecta could be bioaccumulated to a detectable level in G. dominans. Wolfe et al. (1994) also reported that the heterotrophic dinoflagellate Oxyrrhis marina accumulated trace amounts of DMSP when fed on D. tertiolecta.

\section{DISCUSSION}

Since Charlson et al. (1987) hypothesized that oceanic production of DMSP and DMS could significantly affect the global climate (known as the CLAW hypothesis), interest in DMSP dynamics has increased rapidly (e.g. Kiene et al. 1996, Stefels et al. 2000). Most DMSP studies have focussed on phytoplankton and bacteria, whereas little is known of the roles of grazers and higher consumers. Protozoans and other microzooplankton are major grazers in the ocean, especially in areas dominated by small phytoplankton such as solitary Phaeocystis sp. cells (Weisse \& Scheffel-Möser 
1990, Archer et al. 2000) and Emiliania huxleyi (Archer et al. 2001, 2002). Recent field studies reported that microzooplankton ingested 43 to $57 \%$ of the algal DMSP stock per day, and channelled 63 to $91 \%$ of phytoplankton-DMSP losses (Archer et al. 2002, Burkill et al. 2002, Simó et al. 2002); thus, the fate of the ingested DMSP will be a key factor in DMSP dynamics. If the micrograzer only acts as a releaser of phytoplankton-DMSP into the dissolved phase, where it is made available to bacteria, then microzooplankton grazing will accelerate the coupling between phytoplankton-DMSP and its transformation products such as DMS. If DMS is produced and released during digestion of the alga by the micrograzer, the coupling between algal DMSP and DMS is still strengthened. Conversely, if DMSP accumulates in the grazer's biomass, it can be further transferred to higher trophic levels and the coupling between DMSP and DMS productions will be weakened. Similar considerations would apply to mesozooplankton.

Retention of ingested DMSP in the protozoan cells is usually deduced indirectly based on the disappearance of algal DMSP and production of known DMSP breakdown products in grazing experiments. For example, Wolfe et al. (1994) observed that when Oxyrrhis marina (heterotrophic dinoflagellate) grazed on Emiliania huxleyi, 30 to $76 \%$ of the ingested DMSP was released as dissolved DMSP, whereas the missing 24 to $70 \%$ was assumed to be metabolized or retained by the grazers. In another laboratory study, Belviso et al. (1990) estimated that ciliates decomposed 40 to $50 \%$ of ingested DMSP and assumed that the remaining 50 to $60 \%$ was retained temporarily in the cells. Christaki et al. (1996) estimated that $>65 \%$ of the prey's DMSP was lost to dissolved form when Isochrysis galbana was grazed by the ciliate Strombidium sulcatum, whereas the remaining portion was thought to be taken up by bacteria or the ciliate. A field grazing experiment in a North Atlantic E. huxleyi bloom showed that $67 \%$ of the ingested DMSP was released by microzooplankton as dissolved DMSP and DMS, and the other $33 \%$ was assumed to be retained in the microzooplankton biomass (Simó et al. 2002). In a similar bloom in the North Sea, Burkill et al. (2002), assuming an uptake efficiency of $30 \%$ for microzooplankton, estimated that $70 \%$ of the phytoplankton-DMSP ingested by microzooplankton was released as dissolved DMSP, only a small fraction $(<7 \%)$ was converted to DMS, and the fate of the remaining fraction ( $>23 \%$ ) was uncertain.

Direct measurement of DMSP in protozoan biomass is difficult due to the fact that protozoans cannot be easily separated from co-existing phytoplankton. In the present study, we allowed Gyrodinium dominans to graze down co-existing phytoplankton and grow to high densities in the laboratory, then concentrated the biomass for measurements. Using this approach we were able to detect the small amount of DMSP in G. dominans cells. However, there was still considerable scatter in the data, and the values tended to be low at the beginning of the incubation when phytoplankton concentrations were relatively high (Tables $3 \& 4$ ). On average, G. dominans retained 0.6 to $1 \times 10^{-4} \mathrm{nmol}$ DMSP cell ${ }^{-1}$. To our knowledge, only one strict heterotroph, the osmotrophic dinoflagellate Crypthecodinium cohnii, has been reported to contain DMSP in culture (Ishida \& Kadota 1967, Keller et al. 1989). The general belief is that heterotrophs are not able to synthesize DMSP de novo, as photosynthesis is a requisite for the biosynthesis chain from sulfate reduction to DMSP formation (Malin \& Kirst 1997). Simó et al. (2002) found a good match between primary production and DMSP biosynthesis over a $2 \mathrm{wk}$ period, as well as over a whole day-night cycle, which indicated that DMSP production was light-dependent and coupled to photosynthesis. Our additional experiment with the dinoflagellate feeding on Dunaliella tertiolecta also supported the argument that $G$. dominans relies on food for DMSP uptake. We also used the copepod Acartia tonsa as a natural agent to concentrate $G$. dominans biomass in their guts to yield measurable DMSP signals. Using this indirect approach we estimated that $G$. dominans contained 0.7 to $1.6 \times 10^{-4} \mathrm{nmol}$ DMSP cell ${ }^{-1}$. Thus the 2 approaches yield similar ranges of DMSP content for $G$. dominans. The indirect approach can be further developed for field applications, especially when direct measurements on protozoan biomass are not feasible. This approach has the advantage that it does not require manipulation of protozoan cells, and that copepods are easy to collect and handle. It does require that one knows the contribution of gut DMSP content from phytoplankton cells, which could be estimated from gut pigment measurements (Harris et al. 2000) and ambient particulate DMSP data. A limitation of the indirect approach is that it does not apply to copepod species that assimilate a substantial amount of ingested DMSP into body tissues (e.g. Tang et al. 1999).

The processing of ingested DMSP by Gyrodinium dominans differed between food types. For example, G. dominans retained ingested DMSP more efficiently when fed on Phaeocystis globosa (44\%) than when fed on Isochrysis galbana (32\%). Regardless of the dietary difference, these values are comparable to other researchers' estimates based on disappearance of food DMSP (24 to $70 \%$ of ingested DMSP, see earlier discussion). It therefore appears that retention in biomass and release in dissolved forms are the 2 main mechanisms by which protozoans process ingested DMSP. Interestingly, TDF was also higher with $P$. globosa (1.00) than with I. galbana (0.63). Thus, with G. dominans as the grazer, the carbon dynamics and DMSP 
dynamics were more tightly coupled in a $P$. globosabased food chain than in an I. galbana-based food chain. By retaining ingested DMSP in their biomass, protozoans can transfer DMSP further up the food chain. In the present study, the omnivorous copepod Acartia tonsa fed on both phytoplankton and G. dominans. However, in the mixed food treatments, the copepods selectively fed on G. dominans, deriving most of their carbon ration by ingesting the protozoan. In terms of DMSP, $A$. tonsa obtained 63 to $84 \%$ of dietary DMSP by feeding on G. dominans in the food mixture. Thus, the predatory food chain appeared to be more important than the direct grazing food chain for transferring DMSP to omnivorous copepods.

Based on this and other studies, protozoans retain $\sim 30 \%$ of ingested DMSP in the cells. In systems where protozoans exert strong top-down control on phytoplankton (e.g. Weisse \& Scheffel-Möser 1990, Archer et al. 2002), one-third of the phytoplankton-DMSP could be channelled through protozoans to higher trophic levels such as copepods. A related question is: What may happen to DMSP within the copepod bodies? In species such as Acartia tonsa, ingested DMSP remains mainly as gut content (Tang 2000, this study) for a relatively short time (e.g. 1 gut passage time) before being channelled to the microbial and detrital food chains via defecation (Tang 2001, Tang et al. 2001b). The copepod species Temora longicornis assimilates part of the ingested DMSP into its body tissues, making it available for higher trophic levels (Tang et al. 1999). The assimilation is a function of ambient salinity and food concentration, and reaches a maximum after which further ingested DMSP is likely disposed of as faecal material or excreta (Tang et al. 1999, 2000a). In a field study, Tang et al. (2000b) found that most mesozooplankton contained very little DMSP; the copepod T. longicornis was the only species with a considerable amount of DMSP. During the months when the zooplankton community was dominated by $T$. longicornis, the zooplankton pool accounted for $>70 \%$ of the particulate DMSP in the water column, whereas at other times, the zooplankton pool of DMSP was negligible (Tang et al. 2000b). Thus, the importance of mesozooplankton as a trophic linkage for transferring DMSP up the food chain highly depends on their species composition.

Acknowledgements. The study was supported by a Carlsberg Foundation (Denmark) research fellowship 99053/20-950 awarded to K.W.T., Spanish Ministerio de Ciencia y Tecnología grant REN2000-2457-E awarded to R.S., and Danish Natural Science Research Council grant 9801393 awarded to Dr. Thomas Kiørboe. We thank Maria Vila for assistance with the sulfur analyses and Dr. Hans H. Jakobsen for providing size measurements on Gyrodinium dominans. Two reviewers and editor Dr. J. Dolan provided constructive comments.

\section{LITERATURE CITED}

Andreae MO (1990) Ocean-atmospheric interactions in the global biogeochemical sulfur cycle. Mar Chem 30:1-29

Andreae MO, Raemdonck H (1983) Dimethyl sulfide in the surface ocean and the marine atmosphere: a global view. Science 221:744-747

Archer SD, Verity PG, Stefels J (2000) Impact of microzooplankton on the progression and fate of the spring bloom in fjords of northern Norway. Aquat Microb Ecol 22:27-41

Archer SD, Widdicombe CE, Tarran GA, Rees AP, Burkill PH (2001) Production and turnover of particulate dimethylsulphoniopropionate during a coccolithophore bloom in the northern North Sea. Aquat Microb Ecol 24:225-241

Archer SD, Smith GC, Nightingale PD, Widdicombe CE, Tarran GA, Rees AP, Burkill PH (2002) Dynamics of particulate dimethylsulphoniopropionate during a Lagrangian experiment in the northern North Sea. Deep-Sea Res II 49: 2979-2999

Belviso S, Kim SK, Rassoulzadegan F, Krajka B, Nguyen BC, Mihalopoulos N, Menard-Buat P (1990) Production of dimethylsulfonium propionate (DMSP) and dimethylsulfide (DMS) by a microbial food web. Limnol Oceanogr 35: 1810-1821

Burkill PH, Archer SD, Robinson C, Nightingale PD, Groom SB, Tarran GA, Zubkov MV (2002) Dimethyl sulphide biogeochemistry within a coccolithophore bloom (DISCO): an overview. Deep-Sea Res II 49:2863-2885

Charlson RJ, Lovelock JE, Andreae MO, Warren SG (1987) Oceanic phytoplankton, atmospheric sulphur, cloud albedo and climate. Nature 326:655-661

Christaki U, Belviso S, Dolan JR, Corn M (1996) Assessment of the role of copepods and ciliates in the release to solution of particulate DMSP. Mar Ecol Prog Ser 141:119-127

Dacey JWH, Wakeham SG (1986) Oceanic dimethylsulfide: production during zooplankton grazing on phytoplankton. Science 233:1314-1316

Daly KL, DiTullio GR (1996) Particulate dimethylsulfoniopropionate removal and dimethylsulfide production by zooplankton in the Southern Ocean. In: Kiene RP, Visscher PT, Keller MD, Kirst GO (eds) Biological and environmental chemistry of DMSP and related sulfonium compounds. Plenum Press, New York, p 223-238

Frost BW (1972) Effects of size and concentration of food particles on the feeding behavior of the marine planktonic copepod Calanus pacificus. Limnol Oceanogr 17:805-815

Hansen PJ, Bjørnsen PK, Hansen B (1997) Zooplankton grazing and growth: scaling within the $2-2000 \mu \mathrm{m}$ body range. Limnol Oceanogr 42:687-704

Harris RP, Wiebe PH, Lenz J, Skjoldal HR, Huntley M (2000) ICES Zooplankton methodology manual. Academic Press, London

Ishida Y, Kadota H (1967) Isolation and identification of dimethyl-propiothetin from Gyrodinium cohnii. Agric Biol Chem 31:756-757

Jakobsen HH, Hansen PJ (1997) Prey size selection, grazing and growth response of the small heterotrophic dinoflagellate Gymnodinium sp. and the ciliate Balanion comatum-a comparative study. Mar Ecol Prog Ser 158: $75-86$

Jakobsen HH, Tang KW (2002) Effects of protozoan grazing on colony formation in Phaeocystis globosa (Prymnesiophyceae) and the potential costs and benefits. Aquat Microb Ecol 27:261-273

Keller MD, Korjeff-Bellows W (1996) Physiological aspects of the production of dimethylsulfoniopropionate (DMSP) by marine phytoplankton. In: Kiene RP, Visscher PT, Keller 
MD, Kirst GO (eds) Biological and environmental chemistry of DMSP and related sulfonium compounds. Plenum Press, New York, p 131-142

Keller MD, Bellows WK, Guillard RRL (1989) Dimethyl sulfide production in marine phytoplankton. In: Saltzman E, Cooper WJ (eds) Biogenic sulfur in the environment. American Chemical Society, Washington, DC, p 167-182

Kettle AJ, Andreae MO, Amouroux D, Andreae TW and 28 others (1999) A global database of sea surface dimethylsulfide (DMS) measurements and a procedure to predict sea surface DMS as a function of latitude, longitude, and month. Global Biogeochem Cycles 13:399-444

Kiene RP, Visscher PT, Keller MD, Kirst GO (1996) Biological and environmental chemistry of DMSP and related sulfonium compounds. Plenum Press, New York

Kiene RP, Linn LJ, Bruton JA (2000) New and important roles for DMSP in marine microbial communities. J Sea Res 43: 209-224

Kirst GO (1996) Osmotic adjustment in phytoplankton and macroalgae. In: Kiene RP, Visscher PT, Keller MD, Kirst GO (eds) Biological and environmental chemistry of DMSP and related sulfonium compounds. Plenum Press, New York, p 121-129

Kwint RLJ, Irigoien X, Kramer KJM (1996a) Copepods and DMSP. In: Kiene RP, Visscher PT, Keller MD, Kirst GO (eds) Biological and environmental chemistry of DMSP and related sulfonium compounds. Plenum Press, New York, p 239-252

Kwint RLJ, Quist P, Hansen TA, Dijkhuizen L, Kramer KJM (1996b) Turnover of dimethylsulfoniopropionate and dimethylsulfide in the marine environment: a mesocosm experiment. Mar Ecol Prog Ser 145:223-232

Lancelot C, Keller MD, Rousseau V, Smith WO Jr, Mathot S (1998) Autecology of the marine haptophyte Phaeocystis sp. In: Anderson DM, Cembella AD, Hallegraeff GM (eds) Physiological ecology of harmful algal blooms. Springer, New York

Levasseur M, Keller MD, Bonneau E, D'Amours D, Bellows WK (1994) Oceanographic basis of a DMS-related Atlantic cod (Gadus morhua) fishery problem: blackberry feed. Can J Fish Aquat Sci 51:881-889

Levasseur M, Michaud S, Egge J, Cantin G and 6 others (1996) Production of DMSP and DMS during a mesocosm study of an Emiliania huxleyi bloom: influence of bacteria and Calanus finmarchicus grazing. Mar Biol 126:609-618

Lovelock JE, Maggs RJ, Rasmussen RA (1972) Atmospheric dimethyl sulphide and the natural sulphur cycle. Nature 237:452-453

Malin G, Kirst GO (1997) Algal production of dimethyl sulfide and its atmospheric role. J Phycol 33:889-896

Mauchline J (1998) The biology of calanoid copepods. Academic Press, London

Menden-Deuer S, Lessard EJ (2000) Carbon to volume relationships for dinoflagellates, diatoms, and other protist plankton. Limnol Oceanogr 45:569-579

Nguyen BC, Gaudry A, Bonsang B, Lambert G (1978) Reevaluation of the role of dimethyl sulphide in the sulphur budget. Nature 275:637-639

Nguyen BC, Bonsang B, Gaudry A (1983) The role of the ocean in the global atmospheric sulfur cycle. J Geophys Res 88:10903-10914

Niki T, Kunugi M, Otsuki A (2000) DMSP-lyase activity in five marine phytoplankton species: its potential importance in DMS production. Mar Biol 136:759-764

Simó R (2001) Production of atmospheric sulfur by oceanic plankton: biogeochemical, ecological and evolutionary links. Trends Ecol Evol 16:287-294

Simó R, Grimalt JO, Albaigés J (1996) Sequential method for the field determination of nanomolar concentrations of dimethyl sulfoxide in natural waters. Anal Chem 68: 1493-1498

Simó R, Malin G, Liss PS (1998) Refinement of the borohydride reduction method for trace analysis of dissolved and particulate dimethyl sulfoxide in marine water samples. Anal Chem 70:4864-4867

Simó R, Archer SD, Pedrós-Alió C, Gilpin L, Stelfox-Widdicombe CE (2002) Coupled dynamics of dimethylsulfoniopropionate and dimethylsulfide cycling and the microbial food web in surface waters of the North Atlantic. Limnol Oceanogr 47:53-61

Stefels J, van Rijssel M, Hansen TA, Dijkhuizen L, Gieskes WWC (2000) Biological and environmental chemistry of DMS(P) and the role of Phaeocystis in marine biogeochemical cycles. J Sea Res 43:179-390

Strathmann RR (1967) Estimating the organic carbon content of phytoplankton from cell volume or plasma volume. Limnol Oceanogr 12:411-418

Tang KW (2000) Dynamics of dimethylsulfoniopropionate (DMSP) in a migratory grazer: a laboratory simulation study. J Exp Mar Biol Ecol 243:283-293

Tang KW (2001) Defecation of dimethylsulfoniopropionate (DMSP) by the copepod Acartia tonsa as functions of ambient food concentration and body DMSP content. J Plankton Res 23:549-553

Tang KW, Dam HG, Visscher PT, Fenn TD (1999) Dimethylsulfoniopropionate (DMSP) in marine copepods and its relation with diets and salinity. Mar Ecol Prog Ser 179: 71-79

Tang KW, Fenn TD, Visscher PT, Dam HG (2000a) Regulation of body dimethyl sulfoniopropionate (DMSP) content by the copepod Temora longicornis: a test of four mechanisms. Mar Biol 136:749-757

Tang KW, Rogers DR, Dam HG, Visscher PT (2000b) Seasonal distribution of DMSP among seston, dissolved matter and zooplankton along a transect in the Long Island Sound estuary. Mar Ecol Prog Ser 206:1-11

Tang KW, Jakobsen HH, Visser AW (2001a) Phaeocystis globosa (Prymnesiophyceae) and the planktonic food web: feeding, growth, and trophic interactions among grazers. Limnol Oceanogr 46:1860-1870

Tang KW, Visscher PT, Dam HG (2001b) DMSP-consuming bacteria associated with the calanoid copepod Acartia tonsa (Dana). J Exp Mar Biol Ecol 256:185-198

Tiselius P (1998) Short term feeding responses to starvation in three species of small calanoid copepods. Mar Ecol Prog Ser 168:119-126

van Duyl FC, Gieskes WWC, Kop AJ, Lewis WE (1998) Biological control of short-term variations in the concentration of DMSP and DMS during a Phaeocystis spring bloom. J Sea Res 40:221-231

Weisse T, Scheffel-Möser U (1990) Growth and grazing loss rates in single-celled Phaoecystis sp. (Prymnesiophyceae). Mar Biol 106:153-158

Welsh DT (2000) Ecological significance of compatible solute accumulation by micro-organisms: from single cells to global climate. FEMS Microbiol Rev 24:263-290

Wolfe GV, Steinke M (1996) Grazing-activated production of dimethyl sulfide (DMS) by two clones of Emiliania huxleyi. Limnol Oceanogr 41:1151-1160

Wolfe GV, Sherr EB, Sherr BF (1994) Release and consumption of DMSP from Emiliania huxleyi during grazing by Oxyrrhis marina. Mar Ecol Prog Ser 111:111-119 